\title{
The Mediating Effect of Sustainable Consumption Attitude on Association between Perception of Sustainable Lifestyle and Sustainable Consumption Practice
}

\author{
Nurul Fardini Zakaria ${ }^{1}$, Husniyah Abdul Rahim ${ }^{1}$, Laily Paim ${ }^{1} \&$ Nurul Farhana Zakaria ${ }^{1}$ \\ ${ }^{1}$ Faculty of Human Ecology, Universiti Putra Malaysia, Selangor, Malaysia \\ Correspondence: Nurul Fardini Zakaria, Faculty of Human Ecology, Universiti Putra Malaysia, 43400 UPM \\ Serdang, Selangor, Malaysia. Tel: 013-265-6518. E-mail: nurulfardini@gmail.com
}

Received: November 22, 2018

doi:10.5539/ass.v15n2p100
Accepted: December 14, 2018 Online Published: January 30, 2019

URL: https://doi.org/10.5539/ass.v15n2p100

\begin{abstract}
The issue of sustainability is increasingly becoming the focus of research activities. In order to achieve sustainability, various parties need to play their role, including the adolescents. However, environmental issues appear to be more critical nowadays. The aim of this study was to determine the relationship between the perception of sustainable lifestyle and sustainable consumption practice among urban adolescents in Selangor, Malaysia. The Structural Equation Modelling analysis was able to measure the impact of mediator sustainable consumption attitude on the relationship between perception of sustainable lifestyle and sustainable consumption practice. Finding of the study showed that sustainable consumption attitude is a partial mediator of the relationship between perception of sustainable lifestyle and sustainable consumption practice. Through this study, factors affecting sustainable consumption practice among adolescents can be identified in detail, subsequently can be used as input in the implementation of sustainable consumption practice programs to help adolescents practice sustainable consumption.
\end{abstract}

Keywords: sustainable consumption practice, perception of sustainable lifestyle, sustainable consumption attitude, and adolescents

\section{Introduction}

Environmental degradation is increasingly critical due to the population growth in developing countries (Zaman, Khan, Khan, Saleem, \& Nawaz, 2011). Malaysia is also dealing with various issues that bring negative impacts on the environment (McLellan, Iyengar, Jeffries, \& Oerlemans, 2014). Based on the statistics, the estimated population of Malaysia in 2018 is 32.4 million as compared to 30.0 million in 2017 with an annual population growth rate of 1.1 percent (Department of Statistics Malaysia, 2018). Consequently, the rapid growth of population in Malaysia has adversely affected the environment. Natural resources in the urban area are depleted at a fast rate due to population pressure (Mei, Wai, \& Ahamad, 2016), and face the challenge of reducing the environmental and natural resource (Bergesen, Suh, Baynes, \& Musango, 2017). Generally, sustainable consumption is linked to the consumption of natural resources that not reduce and diminish resources (Leuenberger \& Bartle, 2009; Saha, 2009), does not affect the ecosystem (Johnson, 2009), and sacrifice the needs of future generations to survive (Morelli, 2013). This clearly demonstrates that the effort in increasing sustainable consumption is seen to help reducing the global environmental problems.

Over the last few decades, consumption has increased worldwide contribute to natural resources depletion, environmental deterioration and biodiversity loss (Kostadinova, 2016). Indeed, the consumption of renewable and non-renewable source of energy has vast environmental effects (Bonevac, 2010). The environmental pressure suggests the needs to stimulate supplementary sustainable consumption (Geels, McMeekin, Mylan, \& Southerton, 2015). Sustainable consumption is emphasized to overcome the impact on modern societies (Liu, Lei, \& Jia, 2017). Furthermore, sustainable consumption is expected to minimize environmental damage (Peattie \& Collins, 2009).

In determining factors affecting the sustainable consumption practice, research on adolescents is important as identity formed in adolescence may reflect values, attitudes and lifelong behaviors (Alwin \& McCammon, 2003; Browne, Garst, \& Bialeschk, 2011; Percy-Smith \& Burns, 2013). In addition, attitude also affects the recycle 
practice (Barr, 2007; Omran, Mahmood, Abdul Aziz, \& Robinson, 2009). This shows that sustainable consumption attitude influence the sustainable practice. Researcher agreed that attitude is a latent variable and could not be viewed directly in the hypothesis development (Ajzen, 2005).

Young consumers are considered crucial to involve in the formation and routinization of mainstream unsustainable consumption practice and pattern (Heiss \& Marras, 2009). Materialistic tendencies are initiated by advanced decision-making strategies among adolescents as at the stage of consumer socialization (Roedder, 2008). Therefore, it is important to identify factors that determine sustainable consumption practice among adolescents through various initiatives that are compatible with themselves. Studies proved that attitude is a powerful predictor of environmental pro-behavior (Juárez-Lugo, 2010; Kaiser \& Fuhrer, 1999; Makki, Abd el Khalick, \& Boujaoude, 2003; Heyl, Moyano Díaz, \& Cifuentes, 2013). Even, determining human attitude allows to predict and change human behavior (Aminrad, Zakariya, Hadi, \& Sakari, 2013).

This study ascertains the effect of perception of sustainable lifestyle and sustainable consumption attitude in contributing to the sustainable consumption practice among urban adolescents. The research population were secondary schools' pupils in an urban area in Selangor, Malaysia. Referring to the Department of Statistics Malaysia (2013), the highest density of adolescents are those living in an urban area in Selangor. The research sample involved Form Four pupils upon approval by the Malaysia Department of Education.

The aim of this study was to determine the relationships between the perception of sustainable lifestyle and sustainable consumption attitude with sustainable consumption practice among urban adolescents. Specifically, there are three objectives in this study: 1) to measure the levels of perception of sustainable lifestyle, sustainable consumption attitude and sustainable consumption practice of urban adolescents; 2) to determine the relationship between perception of sustainable lifestyle and sustainable consumption practice of urban adolescents; 3) to measure the impact of mediator sustainable consumption attitude on the relationship between perception of sustainable lifestyle and sustainable consumption practice.

\section{Theoretical Background}

According to Hargreaves, Longhurst, and Seyfang (2013), fundamental changes that affect the lives and lifestyles of individuals are rarely achieved because of the social and cultural factors influencing practices and behaviors. Because of these social and cultural factors, it is very challenging in achieving more sustainable consumption patterns by changing everyday practices (Bellotti \& Mora, 2016). Social Practice Theory is a sociological theory that approaches behavioral change in such a way and hereby moves away from using rational choice as the driving force of human behavior.

Through this approach, Social Practice Theory provides a more holistic and grounded perspective on behavior change processes as they occur in place and become a great addition to traditional behavior change methods (Hargreaves, 2011; Strengers, Moloney, Maller, \& Horne, 2015), or even replace them (Shove, 2010; Shove, Pantzar, \& Watson, 2012; Spurling \& McMeekin, 2015). This will figure out the choices or decisions taken and also explain why selected practice is performed (Morris, Marzano, Dandy, \& O’Brien, 2012).

Referring to the Social Constructivism Theory, knowledge is based on experiences and not enough to figure the reality (Ertmer \& Newby, 2013). Most previous studies focus on shaping the adolescent sensitive environmental attitude through a variety of experiences (Eagles \& Demare, 1999; Tikka, Kuitunen, \& Tynys, 2000). The individual experiences are influenced by perception and related to the individual and community value system (Litva \& Eyles, 1995). Therefore, Social Practice Theory and Social Constructivism are applied to explain the sustainable consumption practice of urban adolescent and illustrate how the practice is based on adolescent perception and attitude factors.

\subsection{Sustainable Consumption Practices}

Commonly, there are three main phases of consumption which includes acquisition, usage and disposal (MacInnis \& Folkes, 2010). The importance of all three phases has been stressed in various definitions of sustainable consumption (Fischer et al., 2012). Sustainable consumption practice includes four key principles in resource management which are rethink, reduce, reuse and recycle (Norhasmah et al., 2004).

There are several examples of sustainable consumption practice that can be practiced by individuals. The positive practices include reducing energy consumption at home (Semenza et al., 2008), making compost and turn off lights (Cardwell, 2011). There are various inclinations of individuals to act in a sustainable way. In fact, individuals who tend to engage in sustainable consumption practice are those who believe that environmental problems lie on themselves (Nancarrow, Leviston, \& Tucker, 2009; Syme \& Nancarrow, 2006).

However, studies by Aini, Fakhrul'l-Razi, and Nurizan (2007), found that only ten percent of secondary school 
students in Malaysia were able to identify environmental issues and adopt the principle of sustainable consumption in their daily lives. Meanwhile, the study among Form Four pupils in Kluang, Johor found that adolescents are less likely to adopt a sustainable practice in everyday life (Sanacey, Harun, \& Ahmad, 2013).

\subsection{Perception of Sustainable Lifestyle}

According to Mehta and Heble (2015), perception elements consists of composing and interpreting the judgment, making decisions and it is a continuous process. Sustainable lifestyle interventions have three basic components. The first is refuse; referred as involves targeting change of individual behavior that conserves negative impacts on the environment or society. The second component is effuse; seeks to encourage behaviors that have minimal and/or positive impacts. While the third component is refuse; discourages harmful choices (Akenji \& Chen, 2016).

Nevertheless, studies on the perceptions of secondary students in Turkey by Incekara and Tuna (2011), found that students' perceptions and action towards environmental problems were still low. Whereas, the perception survey on sustainable lifestyle among Polytechnic students in Ghana by Asuamah, Felix, and Darkwa (2012), indicates that the majority of respondents perceive that human are destroying nature and dissipate the environment and agreed that pollution affects them. Hence, the following hypothesis is proposed:

$\mathrm{Ha}^{1}$ : There is a significant relationship between perception of sustainable lifestyle and sustainable consumption practice.

\subsection{Sustainable Consumption Attitude}

The term sustainable consumption attitude refers to the set of beliefs, effects, interests, and intentions of a person's behavior regarding environmental issues or activities (Othman et al., 2013). According to Barraza (2001), perceptions and attitudes do not exist separately in individuals. Meanwhile, according to environmental psychologists, the sustainable consumption attitude refers to a positive attitude towards the environment. The attitude that is more favorable to the environment and tends to feel morally forced to act to correct the negative impacts of human interaction with the environment (Stern, 2000). Traditionally, the attitude of sustainable consumption involves several aspects of the environment such as air quality or involves environmental conservation practices, such as recycling (Kaiser, Oerke, \& Bogner, 2007).

Nonetheless, the previous studies found that young people were more reluctant to adopt sustainable consumption, though often having a more positive attitude towards the environment compared to elderly (Diamantopoulos, Schlegelmilch, Sonkovics, \& Bohlen, 2003; Thomson, 2008; Grønhøj \& Thøgersen, 2009; Johnson, Bowker, \& Cordell, 2004). This is in line with the findings by Mohd Yusop, Jailani, and Ahmad (2003), found that students' attitudes are at a positive level but sustainable practice is at a moderate level. Instead, there is a comment about Malaysian attitude, even though they are aware of the importance of preserving the environment, they choose to be indifferent (Abdul Latiff, Samsudin, Latiffah, \& Fauziah, 2012).

Empirical studies confirm that the sustainable consumption attitude is a valid predictor of individual ecological activities, such as recycling and reuse practices, as well as conservation and waste management (Barr, 2007; Vining, \& Ebreo, 1992). Generally, protecting the environment is focused on recycling as it offers the most appropriate solution to the economic and ecological aspects of waste management (Coelho \& de Brito, 2013). In conclusion, the sustainable consumption attitude affects sustainable consumption practice. While some other researchers (Epstein \& Rogers, 1995; Ervin \& Ervin, 1982), suggest that perception is fundamental to attitudes and actions. Hence, the following hypothesis is suggested:

$\mathrm{Ha}^{2}$ : Sustainable consumption attitude mediates the relationship between sustainable lifestyle and sustainable consumption practice.

\section{Method}

According to Creswell (2009), the problem of social studies requires a specific approach. For identifying factors that influence the study rate, the quantitative approach is the best applied. A cross-sectional design using survey method was employed to assess information from the respondents. Sample selection has been made randomly to provide equal opportunities for individuals to be involved as samples of this study to represent the population being studied (Konting, 2000). Based on statistics, Selangor has the highest number of an urban adolescent in Malaysia (Department of Statistics Malaysia, 2013). Hence, urban adolescents in Selangor have been selected as the research sample. This study employed a random sampling design procedure through multi-stage random sampling. The first stage involves a random selection of four districts. In the second stage, for each selected district, three schools in the urban area have been randomly selected. However, the number of schools involved depends on the cooperation and willingness to cooperate in this study. Furthermore, three classes were chosen by 
the school that would be involved as the sample. The recorded number of secondary school students for the year 2017 in Selangor are 338,342 (Ministry of Education Malaysia, 2017). According to Dilman (2007) if the research population around $1,000,000$, the needed sample size is 1090 at $95 \%$ confidence level with $\pm 3 \%$ error levels. The completed questionnaires collect are 911 set. Since structural equation modeling using AMOS software is quite sensitive to missing value, after screening and cleaning, the total sample size was reduced to 877 sets. This number represents $81.20 \%$ of return rate with adjusting estimated response rate in a range of $70 \%$ to $80 \%$ as suggested by Pallant (2010).

Of these participants, $39.8 \%$ of them were male and $60.2 \%$ were female. The elective subjects of Science and Mathematics (44.4\%) account for the biggest portion on the sample followed by subject Languages and Literature (27.0\%), Technical and Vocational (25.2\%) and Social Sciences \& Religion (3.4\%). The majority of respondents are aged 16 years old $(96.2 \%)$, followed by 17 years old $(3.0 \%), 15$ years old $(0.7 \%), 14$ and 20 years old respectively $0.1 \%$.

\subsection{Instrumentation}

Self-administered questionnaire forms were distributed to the respondents. The variables being measured used measurements adopted from previous studies related to sustainable consumption practice, perception of sustainable lifestyle and sustainable consumption attitude.

\subsubsection{Sustainable Consumption Practice}

Sustainable consumption practice as the dependent variable was determined using a three-point scale of practice adopted from Othman, Mohd Salleh, Musrifah, and Mat Arisah (2013). Overall, four items were involved in sustainable consumption practice. CFA model values were: Chi-square $=32.859$, Chi-square $/ \mathrm{df}=3.651, \mathrm{df}=9$, RMSEA $=0.055, \mathrm{p}=0.000, \mathrm{GFI}=0.988, \mathrm{NFI}=0.969, \mathrm{CFI}=0.977, \mathrm{TLI}=0.962$. The four main components of sustainable consumption practice were: properly dispose of waste (d_11), completely turn off the water tab (d_12), turn off the electrical switch after use (d_14) and use both sides of the sheet of paper (d_15).

\subsubsection{Perception of Sustainable Lifestyle}

The perception of sustainable lifestyle measurements consist of five statements on four-point Likert scale from 1 to 4 with 1 (strongly disagree) to 4 (strongly agree). The measurement items were adopted from the instruments by Naimah and Nurizan (2013). The value of the CFA model were: Chi-square $=28.156$, Chi-square $/ \mathrm{df}=5.631$, $\mathrm{df}=5, \mathrm{RMSEA}=0.073, \mathrm{p}=0.000, \mathrm{GFI}=0.988, \mathrm{NFI}=0.954, \mathrm{CFI}=0.962$ and $\mathrm{TLI}=0.924$.

The selected items for the perception of sustainable lifestyle construct were: materialistic life can affect future generations (e_2), we need to save resources (money, time etc) (e_4), selfishness attitude in using resources leads to environmental damage (e_8), personal responsibility is important in protecting environmental pollution (e_14) and environmental protection is more important than economic development (e_20).

\subsubsection{Sustainable Consumption Attitude}

Measurement of items for the sustainable consumption attitude used a Likert scale from 1 (strongly disagree) to 4 (strongly agree) adopted from Laily, Sharifah Azizah, Nurizan, Aini, Norhasmah, and Naimah (2004). After the modification, the CFA model values were: Chi-square $=18.221$, Chi-square $/ \mathrm{df}=3.644, \mathrm{df}=5, \mathrm{RMSEA}=0.055$, $\mathrm{p}=0.000, \mathrm{GFI}=0.992, \mathrm{NFI}=0.984, \mathrm{CFI}=0.988$ and $\mathrm{TLI}=0.976$. The selected items for sustainable consumption attitude construct were; I will make sure the bottle and cans recycled (c_2), I will make sure the fan is used when necessary (c_5), I will make sure to turn off the light when not in use (c_6) and I will make sure to not throwing garbage anywhere (c_7).

According to Watling and Zhou (2012), attitude can be influenced by the choice of behavioral consumption, for example, high individual desires will negatively affecting sustainability. In fact, according to McComb (2002), when conducting a study on the consumption attitude, respondents' attitude can influence the answer given by using two techniques. Firstly ask respondents to make a choice and secondly ask their level of willingness.

\subsection{Measurement Model}

Table 1. Validity

\begin{tabular}{ccc}
\hline Construct & AVE & CR \\
\hline Sustainable consumption practice & 0.625 & 0.725 \\
Perception of sustainable lifestyle & 0.626 & 0.682 \\
Sustainable consumption attitude & 0.670 & 0.813 \\
\hline
\end{tabular}


The study empirically assessed the proposed research model with the most common SEM estimation procedure which is maximum likelihood estimation. This was done by utilizing a two-step structural equation modeling using AMOS software. The first step was conducted to assess the measurement model as shown in Figure 1. Table1 shows the average variance extracted (AVE) and composite reliability (CR) of constructs.

To assess discriminant validity for the research variables, the AVE for the variables were calculated (Hair, Black, Babin, Anderson, \& Anderson, 2010). According to Awang, Afthanorhan, and Asri (2015), the AVE should be more than 0.5 for the validity to achieve. Based on the AVE provided in Table 1, the values range from 0.625 to 0.670 which indicated that the validity was achieved (Anderson \& Gerbing, 1988; Hair et al., 2010). Meanwhile, composite reliability (CR) should be 0.6 or higher based on Awang et al. (2015). The value of CR in this study was higher than required, therefore the composite reliability for the constructs was achieved.

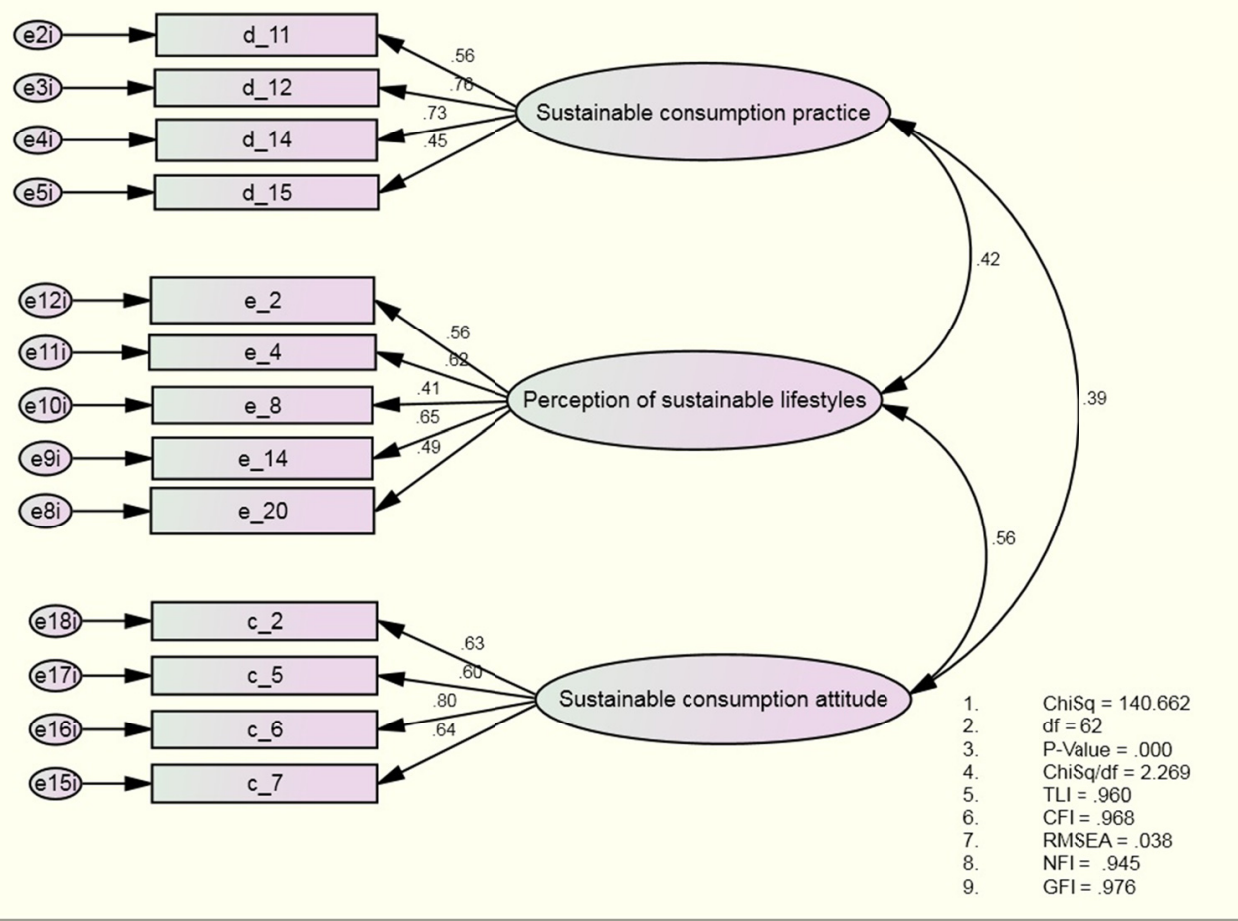

Figure1. Measurement model

\section{Results}

\subsection{Perception of Sustainable Lifestyle}

In this section, the researchers have provided five items of questions for respondents to respond to the perception of sustainable lifestyle. The total score of the respondents' responses reflects the perception of sustainable lifestyle were divided into two levels (negative and positive). The higher the score shown, the more positive the perception of the sustainable lifestyle. While lower mean scores reflect the negative perception of sustainable lifestyle. In order to divide the sample into two groups, the median split are using as a cut-off point. The division of scores for each level uses a statistical approach based on the value of the cut-off point as in Table 2.

Table 2. Categories of perception of sustainable lifestyle

\begin{tabular}{cc}
\hline Variable categories & Mean score \\
\hline Negative & $<5.00$ \\
Positive & $5.00-15.00$ \\
\hline
\end{tabular}

The detailed analysis found that 538 adolescents $(61.3 \%)$ had a positive perception of sustainable lifestyle. On the other hand, the negative perception of sustainable lifestyle was among 339 adolescents (38.7\%) as presented in Figure 2. A survey on sustainable consumption and lifestyle was conducted by UNESCO and the World Bank in 24 countries. Respondents shared a great deal of value, but social implications of production and consumption 
seem more important in Africa, Asia and Latin America than in other parts of the world. According to adolescents, the most important challenge in the future is reducing pollution, improving people's health and respecting human rights (World Bank, 2000). This indirectly encourages a positive perception of sustainable lifestyle among adolescents. In fact, studies were found that Asian adolescents make environmental changes in their communities towards a more sustainable lifestyle (Singh, 2012).

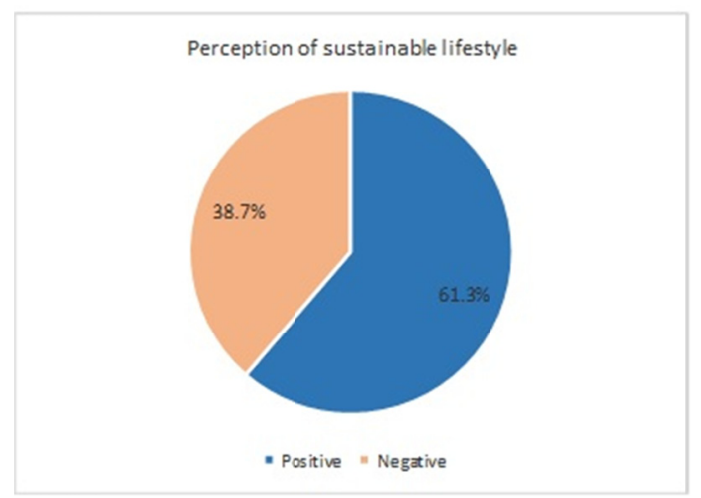

Figure 2. Categories of perception of sustainable lifestyle

\subsection{Sustainable Consumption Attitude}

Attitude is an assessment of positive or negative dimensions (Gilovich, Keltner, Chen, \& Nisbett, 2013). According to Eilam and Trop (2012), a positive attitude leads to positive behavior (Hungerford \& Peyton, 1976). This study used five items to measure the sustainable consumption attitude based on the level of adolescent consent to the attitude of recycling bottle and beverage cans, waste disposal, fan and light usage. The total score of respondents' responses reflects the sustainable consumption attitude which was divided into two categories (negative and positive). The higher score shows a more positive sustainable consumption attitude. While the lower score shows a more negative sustainable consumption attitude. The median split was used as a cut-off point in order to divide. The division of scores for each category uses a statistical approach based on the value of cut-off point as in Table 3 .

Table 3. Category of sustainable consumption attitude

\begin{tabular}{cc}
\hline Variable category & Mean score \\
\hline Negative & $<13.00$ \\
Positive & $13.00-15.00$ \\
\hline
\end{tabular}

The detailed analysis found that 496 adolescents (56.6\%) had a positive sustainable consumption attitude compared to 381 adolescents (43.4\%) with negative sustainable consumption attitude (Figure 3). A person who has a positive attitude towards an object tends to act positively, shows concern, supports and helps the object. Whereas individuals who have a negative attitude towards an object tend to be unconcerned, abandon or criticize (Aydin \& Bakirci, 2007).

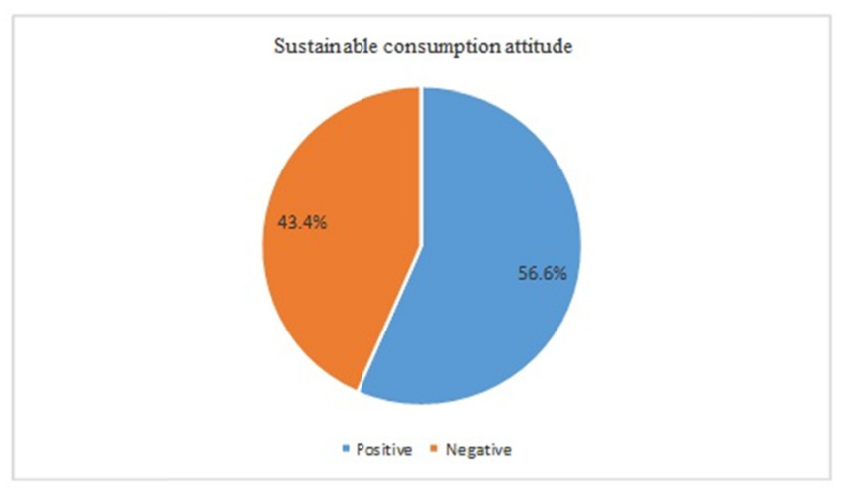

Figure 3. Category of sustainable consumption attitude 


\subsection{Sustainable Consumption Practice}

Sustainable consumption practice is a concept that emphasizes the conservation and preservation of natural resources in every practice and activity carried out (Shahrom et al., 2009). For this variable in the questionnaire, researchers have provided four items for respondents to response regarding sustainable consumption practice. The total number of respondents' answers indicates sustainable consumption practice was divided into three levels (high, moderate and low). The higher the score, the higher the level of sustainable consumption practice and vice-versa. The respondents are divided into three groups using the percentiles split as a cut-off point. The division of scores for each level uses a statistical approach based on the value of cut-off point as shown in Table 4.

Table 4. Level of sustainable consumption practice

\begin{tabular}{cc}
\hline Variable score & Mean score \\
\hline Low & $<10.00$ \\
Moderate & $10.00-11.00$ \\
High & $>11.00$ \\
\hline
\end{tabular}

Figure 4 shows the distribution of respondents according to their sustainable consumption practice. The levels of sustainable consumption practice were classified into three levels, namely low, moderate and high. The result results revealed that 264 adolescents $(30.1 \%)$ had a high level of sustainable consumption practice, 397 adolescents $(45.3 \%)$ with a moderate practice level and 216 adolescents $(24.6 \%)$ had a low practice level. The figure shows that majority of the respondents $(45.3 \%)$ were in a moderate level of sustainable consumption practice. Some authors, including Warde (2005), and Shove (2010), argues that the exploration of usage-oriented practices can offer alternative methods for unsustainable consumer problems. Furthermore, the reasons of not having time to recycle, uncomfortable existing recycle systems and recycle stations that are not well managed are among the constraints to practice sustainable consumption (Yakob, Esa, \& Yunus, 2012).

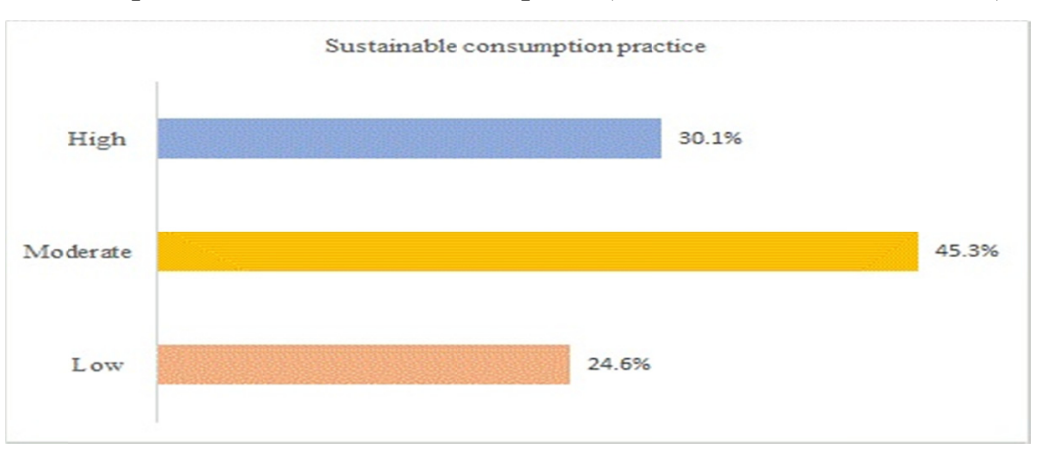

Figure 4. Level of sustainable consumption practice

\subsection{Hypothesis Testing}

The hypothesis test report was based on the significance value of path coefficient with the critical ratio (C.R equivalent to $t$-value) and the value of $p$. According to standard deviation rules, the value of $t$ which is greater or equal to 1.96 and the significance (p) value of less than 0.05 at the 95 percent confidence level indicates that there is a significant relationship between independent and dependent variables (Byrne, 2001).

Table 5. Regression weight for the modified model

\begin{tabular}{llcccc}
\hline Estimate & path & S.E & t & $p$ \\
\hline Sustainable consumption practice & $\leftarrow \quad$ Perception of sustainable lifestyle & 0.181 & 0.043 & 4.228 & 0.000
\end{tabular}

Note. S.E $=$ Standard Error; $*$ p significant at $<0.01$

The first hypothesis examines the relationship between perception of sustainable lifestyle and sustainable consumption practice. It was found that the value of $t$ is 4.228 and the value of $p$ is 0.000 (Table 5). This shows that there was a significant relationship between perception of sustainable lifestyle and sustainable consumption practice. Hence, the decision supports hypothesis $\mathrm{Ha}^{1}$. This is parallel to the findings of the study by Asuamah, Felix, and Darkwa (2012), where students who have positive perceptions toward the environment are more 
concern with saving and energy-saving practices.

\subsection{Mediating Effects Analysis}

The results of the mediator test for the relationships between perception of sustainable lifestyles, sustainable consumption attitude and sustainable consumption practice are displayed in Figure 5. In order to conduct a mediator test, a mediator model has been established to determine the direct effect between perception of sustainable lifestyle and sustainable consumption practice (LP). While the indirect effect involves the relationship between perception of sustainable lifestyle (LA) through a sustainable consumption attitude towards sustainable consumption practice (AP).

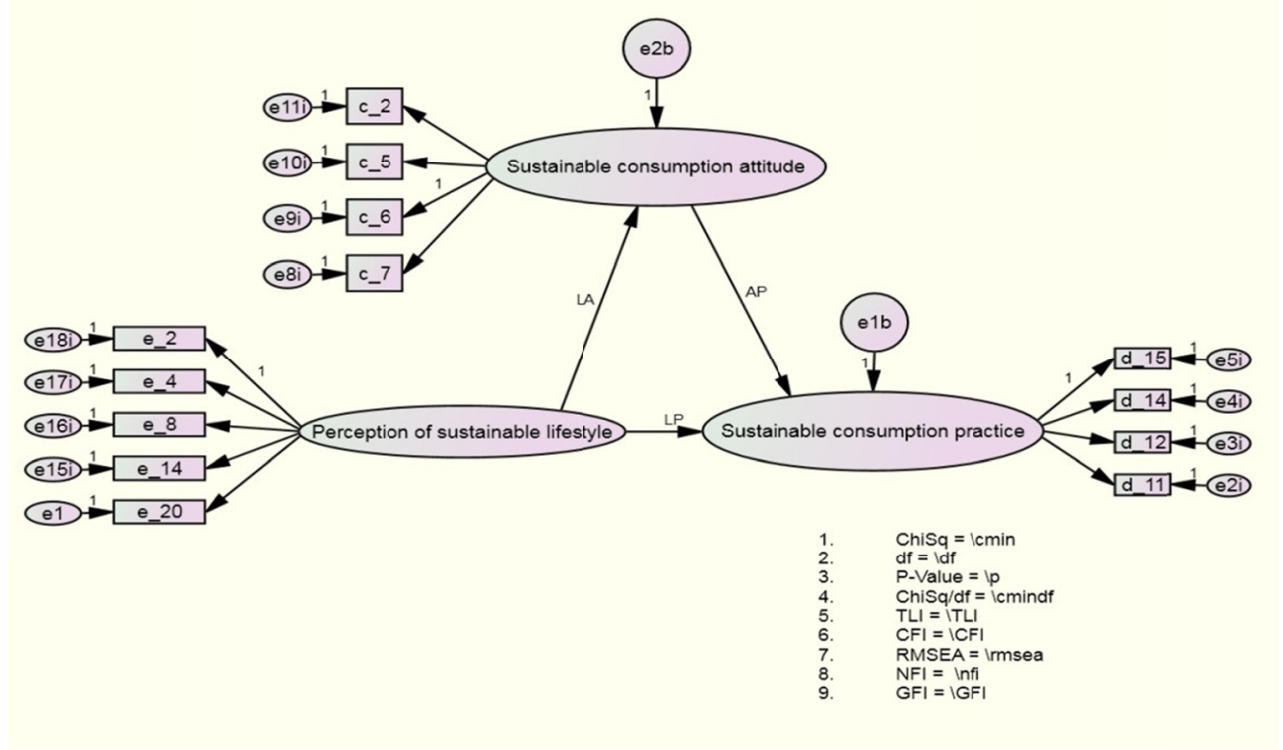

Figure 5. Mediation model

The fit indices of structural model consisted of RMSEA $=0.38, \mathrm{CFI}=0.968, \mathrm{NFI}=0.945, \mathrm{TLI}=0.960$, and $x^{2} / \mathrm{df}=$ 2.269. The GOF indices revealed that TLI and CFI have significantly passed the cut-off point of 0.90 . additionally, the RMSEA value of 0.38 (below 0.8 ) was found to be satisfactory of model fit. Besides, with the chi-square/df value of 2.269 (below 0.5 ), it indicated the model have satisfactory fit. On the other hands, the NFI value of 0.945 identified passed the minimum value of 0.90 . NFI and CFI are from the same category of incremental fit indices (Byrne, 2010). Hence the proven model fit in the measurement model, the test of hypothesis has proceeded. There are two stages involved (1) determine the direct effect of independent variables without mediation variable (Figure 6); (2) determine the direct structural model with mediation variable in the model (Figure 7).

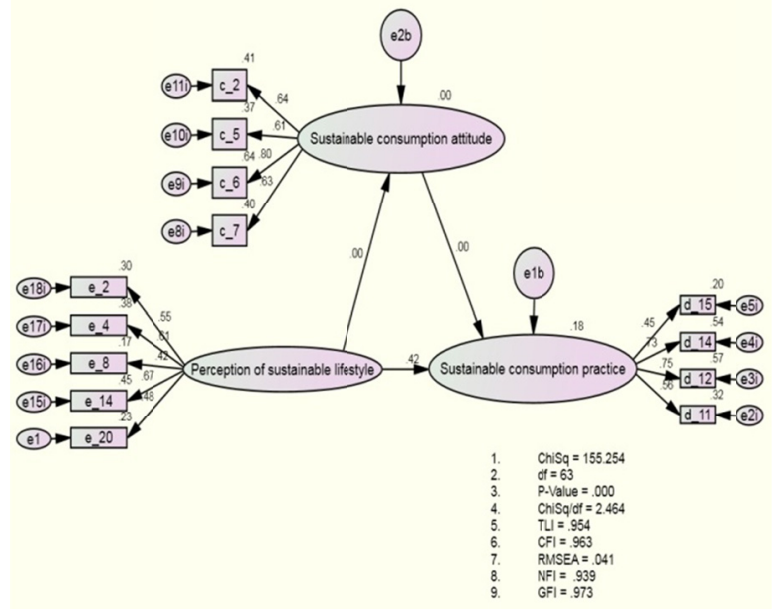

Figure 6. Direct model without mediation

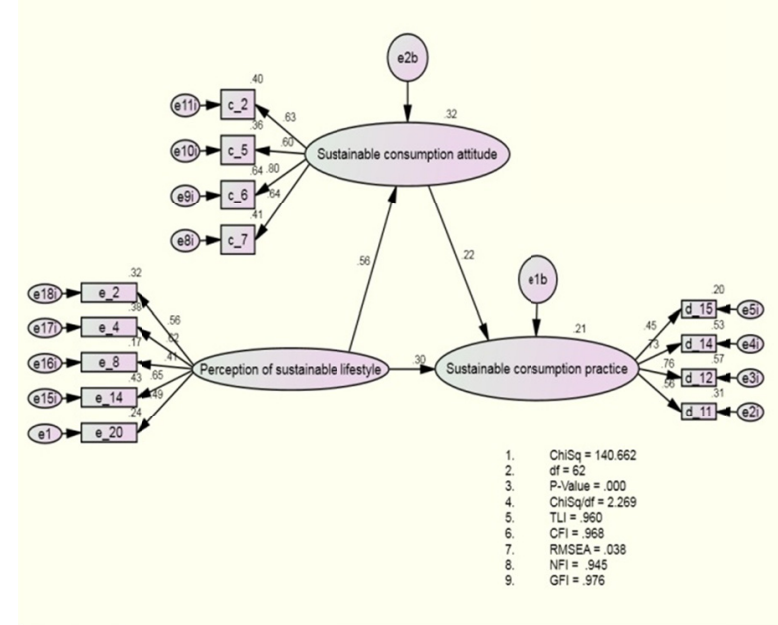

Figure 7. Mediation model 
Subsequently, the mediator test was carried out to determine the effect of sustainable consumption attitude on the relationship between the perception of sustainable lifestyle with sustainable consumption practice. As illustrated in Table 6, standardized direct effect showed there was a significant direct effect found between perception of sustainable lifestyle and sustainable consumption practice (beta coefficient $=0.385, p=0.000$ ). According to the guides by Baron and Kenny (1986), significant relationships for the direct model and full mediation model with reduction of Beta values indicate a partial mediator. Referring to the results presented, the causal effect of perception of sustainable lifestyle (beta coefficient $=0.385, p=0.000$ ) on sustainable consumption practice (beta coefficient $=0.216, p=0.000$ ) was reduced but still remain significant. Based on the guide by Baron and Kenny (1986), the results show that sustainable consumption attitude was a partial mediator of the relationship between perception of sustainable lifestyle and sustainable consumption practice. Significance tests can be applied to test the partial mediation and support inferences as suggested by Baron and Kenny (1986). Hence, hypothesis $\mathrm{Ha}^{2}$ was supported.

According to Brida, Osti, and Faccioli (2011), it is important to understand human reactions and analyze their consumption attitude in an effort to determine the human perception of sustainability issues. Furthermore, attitude is a better predictor of behavior than other variables (Padel \& Foster, 2005; Tanner \& Kast, 2003). In fact, attitude also illustrates behavior (Young, Hwang, McDonald, \& Oates, 2010).

Table 6. Result of Mediation Effect of Sustainable Consumption Attitude on the Relationship between Perception of Sustainable Lifestyle and Sustainable Consumption Practice

\begin{tabular}{cccccc}
\hline Hypothesized path & $b$ & SE & Beta & CR & $p$ \\
\hline Direct Model : & & & & & \\
Mediation Model : & 0.592 & 0.059 & 0.385 & 9.958 & 0.000 \\
a) Perception of sustainable lifestyle $\rightarrow$ Sustainable consumption practice & & & & & \\
b1) Perception of sustainable lifestyle $\rightarrow$ Sustainable consumption practice & 0.135 & 0.037 & 0.216 & 3.694 & 0.000 \\
b2) Perception of sustainable lifestyle $\rightarrow$ Sustainable consumption attitude & 0.574 & 0.059 & 0.561 & 9.708 & 0.000 \\
b3) Sustainable consumption attitude $\rightarrow$ Sustainable consumption practice & 0.184 & 0.040 & 0.301 & 4.647 & 0.000 \\
\hline Note $*$ p significant at $<0.01$ & & & & &
\end{tabular}

\section{Discussion}

This study found that the level of adolescents' sustainable consumption attitude was slightly more than half (56.6\%) for the positive attitude. According to Schultz, Shriver, Tabanico, and Khazian (2004), attitudes toward the environment are associated with human believes that they are a part of nature. Consequently, sustainable consumption attitude needs to be enhanced among adolescents in addressing environmental issues as adolescents are future leaders that are responsible for environmental sustainability (Wray-Lake, Flanagan, \& Osgood, 2010).

However, the findings of the study found that less than half of the respondents $(45.3 \%)$ have a moderate level of sustainable consumption practice. Sustainable consumption practices provide a variety of good effects, for instance, helping reduce economic costs and environmental impacts (Sox, Benjamin, Carpenter, \& Strick, 2013). In fact, some research findings in North America, Europe and Australia show that positive human behaviors have benefited the environment (Bulkeley, 2000; Cardwell, 2011; Lorenzoni \& Hulme, 2009; Palutikof, Agnew, \& Hoar, 2004; Semenza et al., 2008). In addition, studies have shown that positive environmental changes also provide financial benefits (O'Connor, Bord, Yarnal, \& Wiefek, 2002; Harrington, Curtis, \& Black, 2008). For example, using energy efficient equipment can reduce electricity bills.

The result also revealed that more than half of the respondents (61.3\%) have a positive perception of sustainable lifestyle. According to Wossink and Boonsaeng (2003), perception is important to be reviewed and become the basis for sustainable development strategies. While Cardwell (2011), explains that according to Litva and Eyles (1995), it is crucial for policymakers to determine how one's experience influences the perception of sustainable lifestyle thus associated with individual value systems and society. This explains that by defining the adolescent experience of the environment, this is seen to help achieve sustainability goals.

The findings of this research confirm that perception of sustainable lifestyle has a significant relationship with sustainable consumption practice in the case of urban adolescents in Selangor, Malaysia. Based on the result, it can be concluded that a significant relationship between perception of sustainable lifestyle and sustainable consumption practice indicates that the positive perception possessed by the respondents on a certain area of 
sustainable lifestyle could help increase their sustainable consumption practice. The researchers have confirmed that perception is a contributing factor to sustainable behavior (Sharma \& Rani, 2014). Society perception is the basis of environmental activity movement as environmental leader tend to rely on society to obtain resource and ideology support such as volunteer and donation to foster environmental conservation (Barkan, 2004). Therefore, the government should convince the society that environmental issues require behavioral change, otherwise the policy will be constrained by a lack of understanding, awareness and concern.

In addition, an examination of the mediating effect of sustainable consumption attitude between the perception of sustainable lifestyle and sustainable consumption practice reveals that sustainable consumption attitude is a partial mediator. According to Brida, Osti, and Faccioli (2011), it is important to understand human reactions and analyze their attitude towards consumption in an effort to determine the human perception of sustainability issues. The empirical study validates that sustainable consumption attitude predicts individual ecology activities such as recycling, reuse and conservation or waste management (Barr, 2007). In conclusion, sustainable consumption attitude affects the relationship between the perception of sustainable lifestyle and sustainable consumption practice among urban adolescents.

\section{Implications and Limitation of the Study}

Perception of sustainable lifestyle among adolescent need to be emphasized in improving their sustainable consumption practice. There are various tendencies for an individual to act in a sustainable way. Even individuals who tend to engage in sustainable consumption practice are those who believe that the environmental problem lies in themselves (Nancarrow, Leviston, \& Tucker, 2009; Syme \& Nancarrow, 2006). Therefore, all parties should always be responsible for every action taken to improve environmental sustainability. This is because, various research findings show that irresponsible practices have contributed to the deterioration of the environment (Taufique, Siwar, Talib, \& Chamhuri, 2014). The information gathered from this study can be referred by policymakers and various related agencies to understand the sustainable consumption practice among urban adolescent through their perception of sustainable lifestyle. This can help in setting up the module of sustainable education and the enhancement of specific policies to adolescents.

Besides that, the finding also revealed that the adolescent has positive sustainable consumption attitude. However, this involved only slightly more than half of the respondents. Sustainable consumption attitude help to increase efforts to protect nature and also reduce the environmental problem (Frey \& Stutzer, 2006). Besides that, sustainable consumption attitude able to bring many positive effects to the community. According to Stern (2000), an individual that have a positive attitude toward environment have significant effect on behaviour and influence the organization's actions. This study is expected to provide a reference to the Department of Education in creating appropriate programs. Through this study, it is hoped that the Malaysia Education Ministry will be able to develop appropriate sustainability and environment modules and further expand the potential of the individual in a comprehensive and integrated manner to create a balanced and harmonious person in terms of consumption aspects.

The findings also indicated that the adolescents were in a moderate level of sustainable consumption practice. Even so, the subtle percentage between low level and a moderate level of sustainable consumption practice in this study should be focused on. The adolescents who are in a moderate level of sustainable consumption practice may have a tendency to fall into the low or high level of sustainable consumption practice if they do not sustain their practices.

According to Yilmaz, Boone, and Andersen (2004), adolescents do not fully understand the importance of sustainable consumption practice. Hence, sustainable consumption practice should always be given priority. This is because, the attitude will reduce the amount of waste by fostering recycle and reuse of waste leading to the better achievement in preserving the environment (Hutchins \& White, 2009; Scally, 2009). Further studies on adolescents in the context of opportunities and obstacles to sustaining the urban environment also should be done (Euromoniter International, 2012). Workshops and seminars focusing on sustainable consumption topics are among the alternatives to improve sustainable consumption attitude, perception of sustainable lifestyle and sustainable consumption practice among adolescents.

As for the limitation of this study, the measurements and concepts of the variables are limited to perception of sustainable lifestyle, sustainable consumption attitude, and sustainable consumption practice. Research findings are also limited to the selected measurements. The sample of this study involves secondary school students in Selangor who live in urban areas as Selangor has the highest urban adolescent population according to Department of Statistics Malaysia (2013). The sample of the study involves Form Four pupils who are not in 
their national examination year so as not to interrupt the focus of those pupils preparing for the national examination.

\section{Acknowledgments}

This research was supported by the Ministry of Higher Education Malaysia under Fundamental Research Grant Scheme and also Universiti Putra Malaysia (UPM) through Universiti Putra Malaysia Grant "GP/2017/9572800".

\section{References}

Abdul, L. A., Latiff, A., Samsudin, A. R., Latiffah, P., \& Fauziah, A. (2012). The understanding of environmental citizenship among Malaysian youths: A study on perception and participation. Asian Social Science, 8(5), 85-92. https://doi.org/10.5539/ass.v8n5p85

Aini, M. S., Nurizan, Y., \& Fakhru'l-Razi, A. (2007). Environmental comprehension and participation of Malaysian secondary school students. Environmental Education Research, 13(1), 17-31. https://doi.org/10.1080/13504620601122616

Ajzen, I. (2005). Attitudes, personality, and behavior. UK: Mcgraw-Hill Education.

Akenji, L., \& Chen, H. (2016). A framework for shaping sustainable lifestyles. United Nations Environment Programme: Nairobi, Kenya.

Alwin, D. F. \& Mccammon, R. J. (2003). Generations, cohorts, and social change. Handbook of the life course, US: Springer.

Aminrad, Z., Zakariya, S. Z. B. S., Hadi, A. S., \& Sakari, M. (2013). Relationship between awareness, knowledge and attitudes towards environmental education among secondary school students in Malaysia. World Applied Sciences Journal, 22(9), 1326-1333.

Anderson, J. C., \& Gerbing, D. W. (1988). Structural equation modeling in practice: A review and recommended two-step approach. Psychological Bulletin, 103(3), 411-423. https://doi.org/10.1037/0033-2909.103.3.411

Asuamah, S. Y., Felix, A. T., \& Darkwa, B. (2012). What is the perception of students towards environmental sustainability? Journal of Natural Sciences Research, 2(10), 114-121.

Awang, Z., Afthanorhan, W. M. A. W., \& Asri, M. A. M. (2015). Parametric and noon parametric approach in structural equation modelling (SEM): The application of bootstrapping. Modern Applied Science, 9(9), 58. https://doi.org/10.5539/mas.v9n9p58

Axsen, J., Tyreehageman, J., \& Lentz, A. (2012). Lifestyle practices and pro-environmental technology. Ecological Economics, 82, 64-74. https://doi.org/10.1016/j.ecolecon.2012.07.013

Aydin, L., \& Bakirci, S. (2007). Geographical distribution of ticks in Turkey. Parasitology Research, 101(2), 163-166. https://doi.org/10.1007/s00436-007-0694-5

Barkan, S. E. (2004). Explaining public support for the environmental movement: A civic voluntarism model. Social Science Quarterly, 85(4), 913-937. https://doi.org/10.1111/j.0038-4941.2004.00251.x

Baron, R. M., \& Kenny, D. A. (1986). The moderator-mediator variable distinction in social psychological research: Conceptual, strategic, and statistical considerations. Journal of Personality and Social Psychology, 51(6), 11-73. https://doi.org/10.1037/0022-3514.51.6.1173

Barr, S. (2007). Factors influencing environmental attitudes and behaviors a UK case study of household waste management. Environment and Behavior, 39(4), 435-473. https://doi.org/10.1177/0013916505283421

Barraza, L. (2001). Perception of social and environmental problems by English and Mexican school children. Canadian Journal of Environmental Education, 6, 139-157.

Bellotti, E., \& Mora, E. (2016). Networks of practices in critical consumption. Journal of Consumer Culture, 16(3), 718-760. https://doi.org/10.1177/1469540514536191

Bergesen, J. D., Suh, S., Baynes, T. M., \& Musango, J. K. (2017). Environmental and natural resource implications of sustainable urban infrastructure systems. Environmental Research Letters, 12(12), 1-13. https://doi.org/10.1088/1748-9326/aa98ca

Bonevac, D. (2010). Is sustainability sustainable? Academic Questions, 23(1), 84-101. https://doi.org/10.1007/s12129-009-9152-4

Gabriel Brida, J., Osti, L., \& Faccioli, M. (2011). Residents' perception and attitudes towards tourism impacts: A 
case study of the small rural community of Folgaria (Trentino-Italy). Benchmarking: An International Journal, 18(3), 359-385. https://doi.org/10.1108/14635771111137769

Browne, L. P., Garst, B. A., \& Bialeschki, M. D. (2011). Engaging youth in environmental sustainability: Impact of the camp 2 grow program. Journal of Park and Recreation Administration, 29(3), 70-85.

Bulkeley, H. (2000). Common knowledge? Public understanding of climate change in Newcastle, Australia. Public Understanding of Science, 9(3), 313-334. https://doi.org/10.1088/0963-6625/9/3/307

Byrne, B. M. (2001). Structural equation modeling with AMOS, EQS, and LISREL: Comparative approaches to testing for the factorial validity of a measuring instrument. International Journal of Testing, 1(1), 55-86. https://doi.org/10.1207/S15327574IJT0101_4

Byrne, B. M. (2010). Structural equation modelling with AMOS (2nd ed.). Routledge Taylor \& Francis Group.

Cardwell, M. (2011). European Union agricultural policy and practice: The new challenge of climate change. Environmental Law Review, 13(4), 271-295. https://doi.org/10.1350/enlr.2011.13.4.271

Coelho, A., \& De Brito, J. (2013). Environmental analysis of a construction and demolition waste recycling plant in Portugal-part I: Energy consumption and CO 2 emissions. Waste Management, 33(5), 1258-1267. https://doi.org/10.1016/j.wasman.2013.01.025

Creswell, J. W. (2009). Qualitative procedures. Research design: Qualitative, quantitative, and mixed methods approaches. California: Sage Publications.

Delli Carpini, M. (2006). Generational replacement. In L. Sherrod, C. A. Flanagan, Department, Griffith University, Brisbane. International Journal of Sustainability in Higher Education, 10(2), 136-151.

Department of Statistics Malaysia. (2018). Current population estimates, Malaysia, 2017-2018. Retrieved from https://www.dosm.gov.my/v1/index.php?r=column/ctwoByCat\&parent_id=115\&menu_id=L0pheU43NWJ wRWVSZklWdzQ4TlhUUT09

Diamantopoulos, A., Schlegelmilch, B. B., Sinkovics, R. R., \& Bohlen, G. M. (2003). Can socio-demographics still play a role in profiling green consumers? A review of the evidence and an empirical investigation. Journal of Business Research, 56(6), 465-480. https://doi.org/10.1016/S0148-2963 (01)00241-7

Dillman, D. A. (2007). Mail and internet surveys: The tailored design method update with new internet, visual, and mixed-mode guide (2nd ed.). New York: John Wiley.

Eagles, P. F., \& Demare, R. (1999). Factors influencing children's environmental attitudes. The Journal of Environmental Education, 30(4), 33-37. https://doi.org/10.1080/00958969909601882

Eilam, E., \& Trop, T. (2014). Factors influencing adults' environmental attitudes and behaviors and the role of environmental schools in influencing their communities. Education and Urban Society, 46(2), $234-263$. https://doi.org/10.1177/0013124512447100

Ertmer, P. A., \& Newby, T. J. (2013). Behaviorism, cognitivism, and constructivism: Comparing critical features from an instructional design perspective. Performance Improvement Quarterly, 26(2), 43-71. https://doi.org/10.1002/piq.21143

Euromonitor International. (2012). The World's Youngest Populations. London: Euromonitor International.

Ervin, C. A., \& Ervin, D. E. (1982). Factors affecting the use of soil conservation practices: Hypotheses, evidence, and policy implications. Land Economics, 58(3), 277-292. https://doi.org/10.2307/3145937

Epstein, W., \& Rogers, S. (Eds.). (1995). Perception of space and motion. San Diego, CA: Academic Press.

Fischer, J., Dyball, R., Fazey, I., Gross, C., Dovers, S., Ehrlich, P. R., ... Borden, R. J. (2012). Human behavior and sustainability. Frontiers in Ecology \& the Environment, 10(3), 153-160. https://doi.org/10.1890/110079

Flanagan, C. (2009). Young people's civic engagement and political development. In Handbook of youth and young adulthood: New perspectives and agendas (pp. 293-300). London: Routledge.

Frey, B. S., \& Stutzer, A. (2008). Environmental morale and motivation. In A. Lewis (Ed.), The Cambridge handbook of psychology \& economic behavior. New York. https://doi.org/10.1017/CBO9780511490118.017

Geels, F. W., McMeekin, A., Mylan, J., \& Southerton, D. (2015). A critical appraisal of sustainable consumption and production research: The reformist, revolutionary and reconfiguration positions. Global Environmental Change, 34, 1-12. https://doi.org/10.1016/j.gloenvcha.2015.04.013

Geiger, S. M., Fischer, D., \& Schrader, U. (2018). Measuring what matters in sustainable consumption: An 
integrative framework for the selection of relevant behaviors. Sustainable Development, 26(1), 18-33. https://doi.org/10.1002/sd.1688

Gilovich, T., Keltner, D., Chen, S., \& Nisbett, R. (2013). Social psychology (3rd ed.). New York: W.W. Norton \& Company, Inc.

Grønhøj, A., \& Thøgersen, J. (2009). Like father, like son? Intergenerational transmission of values, attitudes, and behaviours in the environmental domain. Journal of Environmental Psychology, 29(4), 414-421. https://doi.org/10.1016/j.jenvp.2009.05.002

Hair, J. F., Black, W. C., Babin, B. J., \& Anderson, R. E. (2010). Multivariate data analysis (7th ed.). UpperSaddle River: Pearson.

Hargreaves, T. (2011). Practicing behaviour change: Applying social practice theory to pro environmental behaviour change. Journal of Consumer Culture, 11(1), 79-99. https://doi.org/10.1177/1469540510390500

Hargreaves, T., Longhurst, N., \& Seyfang, G. (2013). Up, down, round and round: Connecting regimes and practices in innovation for sustainability. Environment and Planning A, 45(2), 402-420. https://doi.org/10.1068/a45124

Harrington, C., Curtis, A., \& Black, R. (2008). Locating communities in natural resource management. Journal of Environmental Policy \& Planning, 10(2), 199-215. https://doi.org/10.1080/15239080801928469

Heiss, J., \& Marras, I. (2009). Educating and engaging youth in sustainable consumption: YouthXchange programme. Young people, education and sustainable development: Exploring principles, perspectives and praxis. Netherlands: Wageningen Academic Publisher.

Heyl, M., Moyano Díaz, E., \& Cifuentes, L. (2013). Environmental attitudes and behaviors of college students: A case study conducted at a Chilean University. Revista Latinoamericana De Psicología, 45(3), 487-500. https://doi.org/10.14349/rlp.v45i3.1489

Hungerford, H. R., \& Peyton, R. B. (1976). Teaching environmental education. Portland, ME: J.Weston Walch.

Hutchins, D. C., \& White, S. M. (2009). Coming round to recycling. British Medical Journal (Online), 338.

İncekara, S., \& Tuna, F. (2011). Attitudes of secondary school students towards environmental and sustainable development issues: A case study from Turkey. African Journal of Biotechnology, 10(1), 21.

Jennings, K. E. (2010). Determining the internal consistency of attitude attributions. In proceedings of the 32nd annual conference of the cognitive science society (pp. 978-984). Austin, Texas: Cognitive Science Society.

Johnson, E. (2009). Goodbye to carbon neutral: Getting biomass footprints right. Environmental Impact Assessment Review, 29(3), 165-168. https://doi.org/10.1016/j.eiar.2008.11.002

Johnson, C. Y., Bowker, J. M., \& Cordell, H. K. (2004). Ethnic variation in environmental belief and behavior: An examination of the new ecological paradigm in social psychological context. Environment and Behavior, 36(2), 157-186. https://doi.org/10.1177/0013916503251478

Juárez-Lugo, C. S. (2010). Predictors of recycling behavior among primary school students in Mexico. Psyecology, 1(1), 91-103. https://doi.org/10.1174/217119710790709586

Kaiser, F. G., Wölfing, S., \& Fuhrer, U. (1999). Environmental attitude and ecological behaviour. Journal of Environmental Psychology, 19(1), 1-19. https://doi.org/10.1006/jevp.1998.0107

Kaiser, F. G., Oerke, B., \& Bogner, F. X. (2007). Behavior-based environmental attitude: Development of an instrument for adolescents. Journal of Environmental Psychology, 27(3), 242-251. https://doi.org/10.1016/j.jenvp.2007.06.004

Keys, N., Thomsen, D. C., \& Smith, T. F. (2010). Opinion leaders and complex sustainability issues. Management of Environmental Quality: An International Journal, 21(2), 187-197. https://doi.org/10.1108/14777831011025535

Konting, M. M. (2000). Kaedah penyelidikan pendidikan. Edisi ke-5. Kuala Lumpur: Dewan Bahasa \& Pustaka.

Kostadinova, E. (2016). Sustainable consumer behavior: Literature overview. Economic Alternatives, 2, 224-234.

Laily, P., Syarifah Azizah, H., Nurizan, Y., Aini Mat, S., Norhasmah, S., \& Naimah, S. (2004). Development of an environmental concern index. Malaysian Journal of Consumer and Family Economics, 7, 29-53.

Leuenberger, D., \& Bartle, J. R. (2009). Sustainable development for public administration. Armonk, New York: M.E. Sharp. 
Litva, A., \& Eyles, J. (1995). Coming out: Exposing social theory in medical geography. Health \& Place, 1(1), 5-14. https://doi.org/10.1016/1353-8292(95)00002-4

Lorenzoni, I., \& Hul me, M. (2009). Believing is seeing: Laypeople's views of future socio-economic and climate change in England and in Italy. Public Understanding of Science, 18(4), 383-400. https://doi.org/10.1177/0963662508089540

Liu, Y., Qu, Y., Lei, Z., \& Jia, H. (2017). Understanding the evolution of sustainable consumption research. Sustainable Development, 25(5), 414-430. https://doi.org/10.1002/sd.1671

MacInnis, D. J., \& Folkes, V. S. (2010). The disciplinary status of consumer behavior: A sociology of science perspective on key controversies. Journal of Consumer Research, 36, 899-914. https://doi.org/10.1086/644610

Makki, M. H., Abd-El-Khalick, F., \& Boujaoude, S. (2003). Lebanese secondary school students' environmental knowledge and attitudes. Environmental Education Research, 9(1), 21-33. https://doi.org/10.1080/13504620303468

McComb, G. (2002). A contingent valuation study of Winnipeg municipal water using bounded rationality. Int. J. of Environment \& Sustainable Development, 1(3), 234-248. https://doi.org/10.1504/IJESD.2002.000732

Mehta, S. R., \& Heble, A. (2015). Perceptions of Indians in Oman: Exploring aspects of intercultural communication. In Intercultural communication with Arabs: Studies in educational, professional and societal contexts (pp. 27-39). Springer Singapore. https://doi.org/10.1007/978-981-287-254-8_3

Mei, N. S., Wai, C. W., \& Ahamad, R. (2016). Environmental awareness and behaviour index for Malaysia. Procedia-Social and Behavioral Sciences, 222, 668-675. https://doi.org/10.1016/j.sbspro.2016.05.223

Mohd Yusop, A. H., Jailani, M. Y., \& Ahmad, E. (2003). Meningkatkan pengetahuan, amalan dan sikap terhadap pendidikan alam di kalangan pelajar. Prosiding seminar kebangsaan pengurusan persekitaran. Bangi: Universiti Kebangsaan Malaysia.

Morelli, J. (2013). Environmental sustainability: A definition for environmental professionals. Journal of Environmental Sustainability, 1(1), 2.

Naimah, M. S., \& Nurizan, Y. (2013). Penggunaan lestari dan gaya hidup remaja bandar. Serdang: Penerbit UPM.

National Geographic; Globescan. (2012). Greendex 2012. Consumer choice and the environment $-A$ worldwide tracking survey. Retrieved from http://environment.nationalgeographic.com/environment/greendex/

Nancarrow, B. E., Leviston, Z., \& Tucker, D. I. (2009). Measuring the predictors of communities' behavioural decisions for potable reuse of wastewater. Water Science and Technology, 60(12), 3199-3209. https://doi.org/10.2166/wst.2009.759

Norhasmah, S., Aini, M. S., Laily, P., Sharifah Azizah, H., Nurizan, Y., \& Naimah, S. (2004). Sikap dan amalan terhadap keprihatinan persekitaran. Malaysian Journal of Consumer and Family Economics, 7, 54-65.

Omran, A., Mahmood, A., Abdul Aziz, H., \& Robinson, G. M. (2009). Investigating household's attitude toward recycling of solid waste in Malaysia: A case study. Int. J. of Environmental Research, 3(2), 275-288.

O'Connor, R. E., Bord, R. J., Yarnal, B., \& Wiefek, N. (2002). Who wants to reduce greenhouse gas emissions. Social Science Quarterly, 83(1), 1-17. https://doi.org/10.1111/1540-6237.00067

Othman, M., Mohd Salleh, N., Johari, M., Musrifah, P., \& Mat Arisah, F. (2013). Amalan penggunaan lestari" 4r" dalam kalangan mahasiswa instituti pengajian tinggi (IPT) di Malaysia. J. Pengguna Malaysia, 21, 35-55.

Padel, S., \& Foster, C. (2005). Exploring the gap between attitudes and behaviour: Understanding why consumers buy or do not buy organic food. British Food Journal, 107(8), 606-625. https://doi.org/10.1108/00070700510611002

Pallant, J. (2010). SPSS Survival Manual: A step by step guide to data analysis using SPSS. Maidenhead.

Tanner, C., \& Kast, S. W. (2003). Promoting sustainable consumption: Determinants of green purchases by Swiss consumers. Psychology and Marketing, 20(10), 883-902. https://doi.org/10.1002/mar.10101

Tarrant, M. (2002). Adolescent peer groups and social identity. Social Development, 11(1), 110-123. https://doi.org/10.1111/1467-9507.00189

Peattie, K., \& Collins, A. (2009). Guest editorial: Perspectives on sustainable consumption. International 
Journal of Consumer Studies, 33(2), 107-112. https://doi.org/10.1111/j.1470-6431.2009.00758.x

Percy-Smith, B., \& Burns, D. (2013). Exploring the role of children and young people as agents of change in sustainable community development. Local Environment, 18(3), 323-339. https://doi.org/10.1080/13549839.2012.729565

Roedder, D. (2008). Stages of consumer socialization: The development of consumer knowledge, skills, and values from childhood to adolescence. In C. P. Haugtvedt, P. M. Herr, \& F. R. Kardes (Eds.), Handbook of consumer psychology, Marketing and consumer psychology series (pp. 221-246). Erlbaum, New York, NY.

Ryder, N. B. (1965). The cohort as a concept in the study of social change. American Sociological Review, 30, 843-861. https://doi.org/10.2307/2090964

Saha, D. (2009). Empirical research on local government sustainability efforts in the USA: Gaps in the current literature. Local Environment, 14(1), 17-30. https://doi.org/10.1080/13549830802522418

Sahin, H., \& Erkal, S. (2010). The attitudes of middle school students towards the environment. Social Behaviour and Personality, 38(8), 1061-1072. https://doi.org/10.2224/sbp.2010.38.8.1061

Sanacey, S., Harun, R., \& Ahmad, M. (2013). Amalan penggunaan lestari dalam kalangan pelajar tingkatan empat di daerah Kluang Johor. In Geografi dan alam sekitar dalam pembangunan dantransformasi negara: prosiding persidangan kebangsaan geografi \& alam sekitar kali ke 4. Jabatan Geografi dan Alam Sekitar, Universiti Pendidikan Sultan Idris, Tanjong Malim, Perak, 169-180. ISBN 9789832063681.

Scally, G. (2009). Environmental waste in health care. British Medical Journal, 332, 1343-1344. https://doi.org/10.1136/bmj.b1129

Schultz, P. W., Shriver, C., Tabanico, J. J., \& Khazian, A. M. (2004). Implicit connections with nature. Journal of Environmental Psychology, 24(1), 31-42. https://doi.org/10.1016/S0272-4944(03)00022-7

Semenza, J. C., Hall, D. E., Wilson, D. J., Bontempo, B. D., Sailor, D. J., \& George, L. A. (2008). Public perception of climate change: Voluntary mitigation and barriers to behavior change. American Journal of Preventive Medicine, 35(5), 479-487. https://doi.org/10.1016/j.amepre.2008.08.020

Shahrom, M. Z., Wan Hamidon, W, D., Rahmah, E., Noor Ezlin, A. B., Nuraini, K., Azami, Z., \& Fatihah, S. (2009). Kaji selidik pendidikan alam sekitar dan keperluan kepada pembangunan lestari dalam proses pengajaran dan pembelajaran di fakulti kejuruteraan dan alam bina. Seminar pendidikan kejuruteraan dan alam bina (PeKA09): Kongres Pengajaran Dan Pembelajaran UKM 2009, Fak Kejuruteraan \& Alam Bina.

Sharma, M., \& Rani, L. (2014). Environmentally sustainable consumption: A review and agenda for future research. Global Journal of Finance and Management, 6(4), 367-374.

Shove, E. (2010). Beyond the ABC: Climate Change Policy and Theories of Social Change. Environment and Planning A, 42(6), 1273-1285. https://doi.org/10.1068/a42282

Shove, E., Pantzar, M., \& Watson, M. (2012). The dynamics of social practice (1st ed.). London: SAGE Publications. https://doi.org/10.4135/9781446250655.n1

Singh, P. (2012). Environmental Education in Schools in India and Its Impact on Intergenerational Learning and Environmental Consumerism of Indian Families. Proceedings of the Academy of Marketing Conference, University of Southampton, Southampton, UK.

Sox, C. B., Benjamin, S., Carpenter, J., \& Strick, S. (2013). An exploratory study of meeting planners and conference attendees' perceptions of sustainable issues in convention centers. Journal of Convention \& Event Tourism, 14(2), 144-161. https://doi.org/10.1080/15470148.2013.787662

Spurling, N., \& McMeekin, A. (2015). Interventions in practices: Sustainable mobility policies in England. Social Practices, Interventions and Sustainability. London: Routledge.

Stern, P. C. (2000). New environmental theories: Toward a coherent theory of environmentally significant behavior. Journal of Social Issues, 56(3), 407-424. https://doi.org/10.1111/0022-4537.00175

Steg, L., \& Vlek, C. (2009). Encouraging pro-environmental behaviour: An integrative review and research agenda. Journal of Environmental Psychology, 29(3), 309-317. https://doi.org/10.1016/j.jenvp.2008.10.004

Strengers, Y., Moloney, S., Maller, C., \& Horne, R. (2015). Beyond behaviour change: Practical applications of social practice theory in behaviour change programes. Social practices, interventions and sustainability. London: Routledge.

Syme, G. J., \& Nancarrow, B. E. (2006). Achieving sustainability and fairness in water reform: A Western 
Australian case study. Water International, 31(1), 23-30. https://doi.org/10.1080/02508060608691911

Taufique, K. M. R., Siwar, C. B., Talib, B. A., \& Chamhuri, N. (2014). Measuring consumer's environmental responsibility: A synthesis of constructs and measurement scale items. Curr World Environment, 9(1). https://doi.org/10.12944/CWE.9.1.04

Thomson, R. (2008). National actors in international organizations the case of the European Commission. Comparative Political Studies, 41(2), 169-192. https://doi.org/10.1177/0010414006295661

Tikka, P. M., Kuitunen, M. T., \& Tynys, S. M. (2000). Effects of educational background on students' attitudes, activity levels, and knowledge concerning the environment. The Journal of Environmental Education, 31(3), 12-19. https://doi.org/10.1080/00958960009598640

UNEP (United Nations Environment Programme). (2012). Sustainable, resource efficient cities- Making it happen! Paris, France: UNEP Division of Technology, Industry and Economics. Retrieved from https://wedocs.unep.org/bitstream/handle/20.500.11822/8111/-Sustainable,\%20Resource\%20\%20Efficient $\% 20$ Cities $\% 20 \% 20 \% 20 \% 20 \% 20$ Making $\% 20$ it $\% 20$ Happen!-2012Sustainable_Cities.pdf?sequence=3\&isAl lowed $=\mathrm{y}$.

World Bank. (2000). A guide to world resources 2000 - 2001: People and ecosystems - The Fraying web of life. Washington D.C.: World Resources Institute.

Vining, J., \& Ebreo, A. (1992). Predicting recycling behavior from global and specific environmental attitudes and changes in recycling opportunities. Journal of Applied Social Psychology, 22(20), 1580-1607. https://doi.org/10.1111/j.1559-1816.1992.tb01758.x

Warde, A. (2005). Consumption and theories of practice. Journal of Consumer Culture, 5, 131-153. https://doi.org/10.1177/1469540505053090

Watling, A., \& Zhou, E. (2011). Attitudes towards sustainability: A quantitative study of sustainable (Bachelor's Thesis. Ålidhem Malin Näsholm Student Umeå School of Business). Retrieved from http://www.diva-portal.org/smash/get/diva2:430152/FULLTEXT01.pdf

Wossink, A., \& Boonsaeng, T. (2003). Farmers' knowledge and perceptions of animal waste management technologies: An explorative study for North Carolina. ARE Report, (29), 22-27.

Wray-Lake, L., Flanagan, C. A., \& Osgood, D. W. (2010). Examining trends in adolescent environmental attitudes, beliefs, and behaviors across three decades. Environment and Behavior, 42(1), 61-85. https://doi.org/10.1177/0013916509335163

Yahaya, N., Paim, L., Haron, S. A., Sulaiman, N., Said, A. M., \& Salleh, N. (2004). Penggunaan Lestari: Pemahaman Konsep Asas Dan Pengetahuan Terhadap Kesejahteraan Persekitaran. Malaysian Journal of Consumer and Family Economics, 7, 1-15.

Yakob, N., Esa, N., \& Yunus, H. M. (2012). Exploring secondary school students' belief and attitude about waste management in Northern Peninsular Malaysia. International Journal of Global Education, 1(1).

Yilmaz, O., Boone, W. J., \& Andersen, H. O. (2004). Views of elementary and middle school Turkish students toward environmental issues. International Journal of Science Education, 26(12), 1527-1546. https://doi.org/10.1080/0950069042000177280

Young, W., Hwang, K., Mcdonald, S., \& Oates, C. J. (2010). Sustainable consumption: Green consumer behaviour when purchasing products. Sustainable Development, 18, 20-21.

Zaman, K., Khan, H., Khan, M. M., Saleem, Z., \& Nawaz, M. (2011). The impact of population on environmental degradation in South Asia: Application of seemingly unrelated regression equation model. Environ Econ, 2(2), 80-88.

\section{Copyrights}

Copyright for this article is retained by the author(s), with first publication rights granted to the journal.

This is an open-access article distributed under the terms and conditions of the Creative Commons Attribution license (http://creativecommons.org/licenses/by/4.0/). 